\title{
Author Correction: Variability in historical emissions trends suggests a need for a wide range of global scenarios and regional analyses
}

\author{
Jiesper Strandsbjerg Tristan Pedersen (1D, Detlef P. van Vuuren (1D, Bruno A. Aparício (D), Rob Swart, Joyeeta Gupta \\ \& Filipe Duarte Santos
}

Correction to: Communications Earth \& Environment https://doi.org/10.1038/s43247-020-00045-y, published online 30 October 2020.

The original version of this Article contained errors in the caption of Figs. 1 and 2 and in Fig. 2.

In the caption of Figs. 1 and 2, the description of the colour codes incorrectly read 'low (vermillion), medium-low (bluish-green), medium-high (orange), and high (blue) emissions'. The correct version replaces this description with 'low (bluish-green), medium-low (blue), medium-high (orange), and high (vermillion)'.

In Fig. 2, the label 'RCP' was misplaced and pointed at the 'SSP-BL' scenario estimates, and the label 'SRES' was misplaced and pointed at the 'RCP' scenario estimates (for the 2010 projections in Fig. $2 \mathrm{a}-\mathrm{c}$ ). In addition, not all scenario projections/estimates were labelled.

These errors and omissions have been corrected in both the PDF and HTML versions of the Article.

Published online: 07 December 2020

\footnotetext{
(c) (i) Open Access This article is licensed under a Creative Commons Attribution 4.0 International License, which permits use, sharing, adaptation, distribution and reproduction in any medium or format, as long as you give appropriate credit to the original author(s) and the source, provide a link to the Creative Commons license, and indicate if changes were made. The images or other third party material in this article are included in the article's Creative Commons license, unless indicated otherwise in a credit line to the material. If material is not included in the article's Creative Commons license and your intended use is not permitted by statutory regulation or exceeds the permitted use, you will need to obtain permission directly from the copyright holder. To view a copy of this license, visit http://creativecommons.org/licenses/by/4.0/.
}

(c) The Author(s) 2020 